\title{
Synthesis of Poison-Frog Alkaloids 237D, 207A, and Two Congeners of 235B' for Evaluation to Inhibitory Effect of Nicotinic Acetylcholine Receptors
}

\author{
Naoki ToyookA, ${ }^{*, a}$ Masashi KaWASAKI, ${ }^{b}$ and Hideo Nemoto ${ }^{*, a}$ \\ ${ }^{a}$ Faculty of Pharmaceutical Sciences, Toyama Medical and Pharmaceutical University; 2630 Sugitani, Toyama 930-0194, \\ Japan: ${ }^{b}$ Department of Liberal Arts and Sciences, Faculty of Engineering, Toyama Prefectural University; 5180 \\ Kurokawa, Kosugi-machi, Toyama 939-0398, Japan. \\ Received January 26, 2005; accepted March 7, 2005; published online March 10, 2005
}

Enantioselective synthesis of the poison-frog alkaloids 237D, 207A, and two congeners of 235B' has been achieved. The absolute stereochemistry of $237 \mathrm{D}$ was determined to be $5 S, 8 S, 9 R$ by the present synthesis.

Key words poison-frog alkaloid; 237D; 207A; 235B'; 5,8-disubstituted indolizidine

A large number of biologically active alkaloids have been found in amphibian skin, and the 5,8-disubstituted indolizidines, one of the largest subclass of these alkaloids, were detected from skin extracts of the poison-frog. ${ }^{1-3)}$ Quite recently, we have found the synthetic 5,8-disubstituted indolizidine 235B' (1), isolated from Dendrobates pumilio, acted as a potent noncompetitive and selective blocker of $\alpha 4 \beta 2$ nicotinic receptor $\left(\mathrm{IC}_{50}=74 \mathrm{nM}\right){ }^{4}{ }^{4}$ The sensitivity of 235B' for $\alpha 4 \beta 2$ receptors was comparable with that of the best characterized antagonist of $\alpha 4 \beta 2$ nicotinic acetylcholine reseptors (nAChRs), dihydro- $\beta$-erythroidine $(\mathrm{DH} \beta \mathrm{E})\left(\mathrm{IC}_{50}=\right.$ $0.11 \mu \mathrm{M}){ }^{5}{ }^{5}$ This result shows that poison-frog alkaloids such as indolizidine 235B' alter the function of nicotinic receptors in a subtype-selective manner, suggesting that an analysis of these alkaloids may aid in the development of selective drugs to alter nicotinic cholinergic functions. As part of our ongoing program at directing the synthesis of biologically active alkaloids, ${ }^{6-8)}$ we planned the synthesis of 237D (2, saturated congener of 1$)$, 207A (3, bis-nor congener of 1$)$, nor congener of 235B' (4), and homo congener of 1 (5) as potent blockers for nAChRs. This paper describes a full account of the experiments, some of which were reported in a preliminary communication. ${ }^{9}$ )

The synthesis of 2 began with trisubstituted piperidine $\mathbf{6},{ }^{10,11)}$ which was converted to the $\alpha, \beta$-unsaturated ester 7 in 2-step sequence. Hydrogenation of 7 over $\mathrm{Pd}-\mathrm{C}$ under medium pressure followed by reduction of the ester moiety with Super-Hydride gave rise to the alcohol 8 . Treatment of 8 with $\mathrm{MOMCl}$ in the presence of Hünig base provided the MOM ether 9, which was treated with TBAF to afford the alcohol 10. Swern oxidation of $\mathbf{1 0}$ followed by Wittig olefination of the resulting aldehyde provided the olefin, which was hydrogenated over Pd-C to give rise to the alkaloid 237D (2). The absolute stereochemistry of natural 237D was determined to be $5 S, 8 S, 9 R$ by the present synthesis (see Experimental and reference 9 ).

Swern oxidation of $\mathbf{1 0}$ followed by the Wittig reaction of the resulting aldehyde provided the olefin $\mathbf{1 2}$, which was converted to the alcohol 13. Swern oxidation of $\mathbf{1 3}$ and Wittig reaction of the resulting aldehyde afforded the terminal olefin 14. Deprotection of the urethane moiety in $\mathbf{1 4}$ using Corey's procedure, ${ }^{12)}$ and cleavage of the MOM ether with acid followed by indolizidine formation under the bromination reaction condition ${ }^{13)}$ provided the alkaloid 207A (3), whose spectral data were identical with those of reported values. ${ }^{13,14)}$ On the other hand, the alcohol $\mathbf{1 3}$ was converted to the iodide $\mathbf{1 5}$, and the cross coupling reaction of $\mathbf{1 5}$ using the dibutenyl cuprate gave rise to the homologated olefin 16. Indolizidine formation reaction of $\mathbf{1 6}$ furnished $\mathbf{5}$.

Finally, the nor-congener of $\mathbf{1}(\mathbf{4})$ was synthesized from the
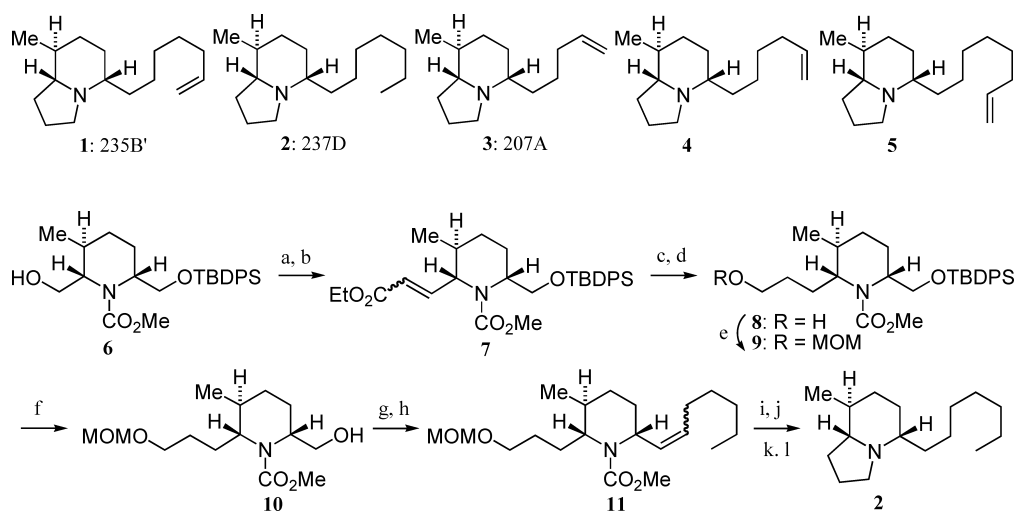

Reagents and conditions: a: Swern ox.; b: (EtO) ${ }_{2} \mathrm{P}(\mathrm{O}) \mathrm{CH}_{2} \mathrm{CO}_{2} \mathrm{Et}, \mathrm{NaH}, \mathrm{THF},{ }^{\circ} \mathrm{C}-\mathrm{rt}(95 \%)$; c: $10 \% \mathrm{Pd}-\mathrm{C}, \mathrm{H}_{2}$, EtOAc, 4 atm; d: Super-Hydride, THF, $0{ }^{\circ} \mathrm{C}(93 \%)$; e: $\mathrm{MOMCl}$, Hünig base $\mathrm{CH}_{2} \mathrm{Cl}_{2}, 0^{\circ} \mathrm{C}-\mathrm{rt}(85 \%)$; f: TBAF, THF, $0{ }^{\circ} \mathrm{C}-\mathrm{rt}(95 \%)$; g: Swern ox.; h: $\mathrm{Me}\left(\mathrm{CH}_{2}\right)_{5} \mathrm{P}^{+} \mathrm{Ph}_{3} \mathrm{Br}^{-}, n$-BuLi, THF, $0{ }^{\circ} \mathrm{C}-\mathrm{rt}(66 \%)$; i: $10 \% \mathrm{Pd}-\mathrm{C}, \mathrm{H}_{2}, \mathrm{EtOAc}, 1 \mathrm{~atm} ; \mathrm{j}: n-$ PrSLi, HMPA, THF, $0^{\circ} \mathrm{C}$-rt; k: conc. $\mathrm{HCl}, \mathrm{MeOH}$, reflux; $1: \mathrm{CBr}_{4}, \mathrm{Ph}_{3} \mathrm{P}_{2} \mathrm{Et}_{3} \mathrm{~N}, \mathrm{CH}_{2} \mathrm{Cl}_{2}, 0^{\circ} \mathrm{C}-\mathrm{rt}(42 \%)$.

Chart 1 


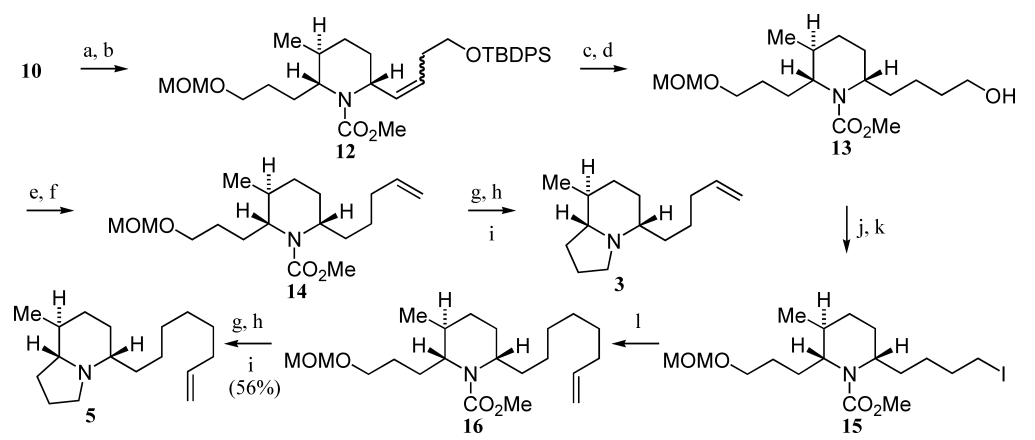

Reagents and conditions: a: Swern ox.; b: TBDPSO $\left(\mathrm{CH}_{2}\right)_{3} \mathrm{P}^{+} \mathrm{Ph}_{3} \mathrm{Br}^{-}, n$-BuLi, THF, $0{ }^{\circ} \mathrm{C}-\mathrm{rt}(87 \%)$; c: $10 \%$ Pd-C, $\mathrm{H}_{2}, \mathrm{EtOAc}, 1$ atm; d: TBAF, THF, $0{ }^{\circ} \mathrm{C}-\mathrm{rt}(87 \%)$; e: Swern

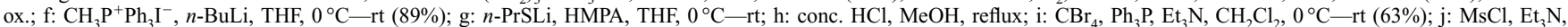
$\mathrm{CH}_{2} \mathrm{Cl}_{2}, 0^{\circ} \mathrm{C}$; $\mathrm{k}$ : NaI, acetone, $50^{\circ} \mathrm{C}(96 \%)$; 1 : butenylmagnesium bromide, CuI, THF, $-40-30{ }^{\circ} \mathrm{C}(91 \%)$.

Chart 2

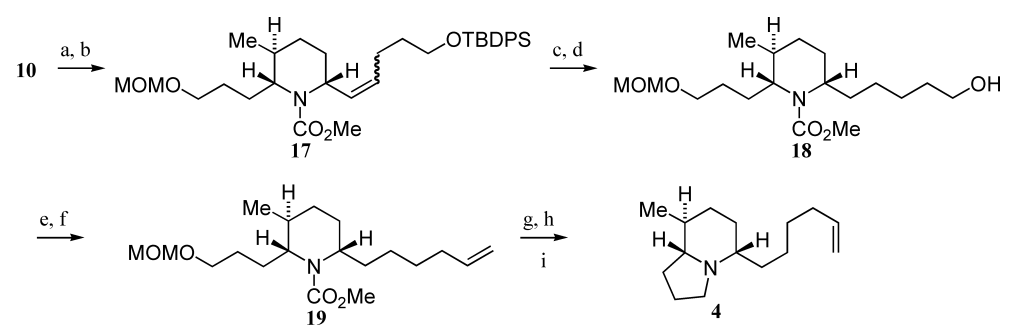

Reagents and conditions: a: Swern ox.; b: TBDPSO $\left(\mathrm{CH}_{2}\right)_{4} \mathrm{P}^{+} \mathrm{Ph}_{3} \mathrm{Br}^{-}, n$-BuLi, THF, $0{ }^{\circ} \mathrm{C}-\mathrm{rt}(97 \%)$; c: $10 \%$ Pd-C, $\mathrm{H}_{2}$, EtOAc, 1 atm; d: TBAF, THF, $0{ }^{\circ} \mathrm{C}-\mathrm{rt}(74 \%)$; e: $\mathrm{Swern}$ ox.; f: $\mathrm{CH}_{3} \mathrm{P}^{+} \mathrm{Ph}_{3} \mathrm{I}^{-}, n$-BuLi, THF, $0^{\circ} \mathrm{C}-\mathrm{rt}(88 \%)$; g: $n$-PrSLi, HMPA, THF, $0^{\circ} \mathrm{C}-\mathrm{rt}$; h: conc. $\mathrm{HCl}, \mathrm{MeOH}, \mathrm{reflux}^{2} \mathrm{i:} \mathrm{CBr}_{4}, \mathrm{Ph}_{3} \mathrm{P}, \mathrm{Et}_{3} \mathrm{~N}, \mathrm{CH}_{2} \mathrm{Cl}_{2}, 0^{\circ} \mathrm{C}-\mathrm{rt}(51 \%)$.

Chart 3

common alcohol $\mathbf{1 0}$ as shown in Chart 3. The alcohol $\mathbf{1 0}$ was converted to the olefin $\mathbf{1 7}$, which was hydrogenated over $10 \%$ $\mathrm{Pd}-\mathrm{C}$ in EtOAc followed by cleavage of silyl ether with TBAF to afford the alcohol 18. Swern oxidation of $\mathbf{1 8}$ and Wittig olefination reaction of the resulting aldehyde provided the terminal olefin 19. Indolizidine formation reaction of 19 in 3-step sequence furnished 4.

Pharmacological studies on the nicotinic acetylcholine receptors of these synthesized indolizidines are now being conducted, and the results will be described in due course.

\section{Experimental}

General ${ }^{1} \mathrm{H}$ - and ${ }^{13} \mathrm{C}-\mathrm{NMR}$ spectra were taken on a Varian Gemini 300 or Unity Plus 500 spectrometer. ${ }^{1} \mathrm{H}-\mathrm{NMR}$ spectra were recorded at the indicated field strength as solutions in $\mathrm{CDCl}_{3}$ unless otherwise indicated. Chemical shifts are given in parts per million (ppm, $\delta$ ) downfield from TMS and are referenced to $\mathrm{CHCl}_{3}(7.26 \mathrm{ppm})$ as internal standard. Splitting patterns are designated as s, singlet; d, doublet; t, triplet; q, quartet; m, multiplet; br, broad. ${ }^{13} \mathrm{C}$-NMR spectra were recorded at the indicated field strength as solutions in $\mathrm{CDCl}_{3}$ unless otherwise indicated. Chemical shifts are given in parts per million (ppm, $\delta$ ) downfield from TMS and are referenced to the center line of $\mathrm{CDCl}_{3}(77.0 \mathrm{ppm})$ as internal standard. Carbon signals were assigned by a DEPT pulse sequence, $\mathrm{q}=$ methyl, $\mathrm{t}=$ methylene, $\mathrm{d}=$ methyne, and $s=$ quaternary carbons. Infrared spectra (IR) were measured with a Perkin-Elmer 1600 series FT-IR spectrophotometer. Mass spectra (MS) and high-resolution mass spectra (HR-MS) were measured on a JEOL JMSAX505HAD mass spectrometer. Optical rotations were measured on a JASCO DIP-1000 digital polarimeter. Column chromatography was performed on Merck silica gel 60 (No. 7734-5B) or (No. 9385).

Methyl 6-(tert-Butyldiphenylsilyloxymethyl)-2-(2-ethoxycarbonylvinyl)-3-methylpiperidine-1-carboxylate (7) To a stirred solution of $(\mathrm{COCl})_{2}(1.15 \mathrm{ml}, 13.19 \mathrm{mmol})$ in $\mathrm{CH}_{2} \mathrm{Cl}_{2}(30 \mathrm{ml})$ was added DMSO $(1.87 \mathrm{ml}, 26.37 \mathrm{mmol})$ at $-78^{\circ} \mathrm{C}$, and the resulting solution was stirred at $-78^{\circ} \mathrm{C}$ for $5 \mathrm{~min}$. To the mixture was added dropwise a solution of $6(4 \mathrm{~g}$, $8.79 \mathrm{mmol})$ in $\mathrm{CH}_{2} \mathrm{Cl}_{2}(6 \mathrm{ml})$ via a double-tipped stainless steel needle. After the reaction mixture was stirred for $30 \mathrm{~min}$ at $-78^{\circ} \mathrm{C}$, triethylamine $(5.47 \mathrm{ml}, 39.56 \mathrm{mmol})$ was added to the reaction mixture. The reaction mixture was warmed to $0{ }^{\circ} \mathrm{C}$ for $1 \mathrm{~h}$, and quenched with $\mathrm{H}_{2} \mathrm{O}$. The aqueous mixture was extracted with $\mathrm{Et}_{2} \mathrm{O}(20 \mathrm{ml} \times 3)$. The organic extracts were combined, dried, and evaporated to give pale yellow oil, which was used directly in the next step.

To a stirred suspension of $\mathrm{NaH}(60 \%, 386 \mathrm{mg}, 9.67 \mathrm{mmol})$ in THF $(20 \mathrm{ml})$ was added $(\mathrm{EtO})_{2} \mathrm{P}(\mathrm{O}) \mathrm{CH}_{2} \mathrm{CO}_{2} \mathrm{Et}(1.94 \mathrm{ml}, 9.67 \mathrm{mmol})$ at $0{ }^{\circ} \mathrm{C}$, and the reaction mixture was stirred for $30 \mathrm{~min}$ at $0{ }^{\circ} \mathrm{C}$. To the mixture was added dropwise a solution of the above aldehyde in THF $(6 \mathrm{ml})$ via a double-tipped stainless needle. The reaction mixture was stirred at room temperature for $20 \mathrm{~h}$, and quenched with $\mathrm{H}_{2} \mathrm{O}$. The aqueous mixture was extracted with $\mathrm{CH}_{2} \mathrm{Cl}_{2}(20 \mathrm{ml} \times 3)$. The organic extracts were combined, dried, and evaporated to give pale yellow oil, which was chromatographed on $\mathrm{SiO}_{2}(80 \mathrm{~g}$, hexane : acetone $=100: 1-10: 1)$ to afford $7(4.29 \mathrm{~g}, 95 \%)$ as a $2: 1$ mixture of $E$ - and $Z$-isomers.

IR (neat) $2955,1759,1698 \mathrm{~cm}^{-1} ;{ }^{1} \mathrm{H}-\mathrm{NMR}(500 \mathrm{MHz}) \delta 0.90,1.11(3 \mathrm{H}$, each d, $J=6.9 \mathrm{~Hz}), 1.05(9 \mathrm{H}, \mathrm{s}), 1.23,1.31(3 \mathrm{H}$, each t, $J=7.2 \mathrm{~Hz}), 1.44$ $2.08(5 \mathrm{H}$, br m), $3.11-3.21(1 \mathrm{H}, \mathrm{brm}), 3.48-3.58(1 \mathrm{H}$, br m $), 3.61,3.71$ $(3 \mathrm{H}$, each s), $4.14-4.22(2 \mathrm{H} \mathrm{m}), 4.33-4.53(2 \mathrm{H} \mathrm{br}), 5.65,5.93(1 \mathrm{H}$, each d, each $J=10.3,14.1 \mathrm{~Hz}), 6.19,6.89(1 \mathrm{H}$, each dd, $J=10.3,8.5,14.1$, $5.5 \mathrm{~Hz}), 7.39-7.48(6 \mathrm{H}, \mathrm{m}), 7.66-7.74(4 \mathrm{H}, \mathrm{m}) ; \mathrm{MS} \mathrm{m} / z: 523\left(\mathrm{M}^{+}\right)$.

Methyl 6-(tert-Butyldiphenylsilyloxymethyl)-2-(3-hydroxypropyl)-3methylpiperidine-1-carboxylate (8) To a stirred solution of $7(1.2 \mathrm{~g}$, $2.29 \mathrm{mmol})$ in EtOAc $(20 \mathrm{ml})$ was added $10 \% \mathrm{Pd}-\mathrm{C}(50 \mathrm{mg})$, and the resulting suspension was hydrogenated under hydrogen atmosphere at $4 \mathrm{~atm}$ for $40 \mathrm{~h}$. The catalyst was removed by filtration and the filtrate was evaporated to give colorless oil, which was used directly in the next step.

To a stirred solution of the above oil in THF $(10 \mathrm{ml})$ was added a solution of Super-Hydride $(1 \mathrm{~m}$ in THF, $5 \mathrm{ml}, 5 \mathrm{mmol})$ at $0{ }^{\circ} \mathrm{C}$, and the resulting solution was stirred at $0{ }^{\circ} \mathrm{C}$ for $1.5 \mathrm{~h}$. The reaction was quenched with ice-water, and the aqueous mixture was extracted with $\mathrm{CH}_{2} \mathrm{Cl}_{2}(10 \mathrm{ml} \times 5)$. The organic extracts were combined, dried, and evaporated to give colorless oil, which was chromatographed on $\mathrm{SiO}_{2}(20 \mathrm{~g}$, hexane : acetone $=30: 1-10: 1)$ to afford $8(1.02 \mathrm{~g}, 93 \%)$ as colorless oil.

IR (neat) 3471, $1688 \mathrm{~cm}^{-1} ;{ }^{1} \mathrm{H}-\mathrm{NMR}(500 \mathrm{MHz}) \delta 0.90$ (3H, br), 1.06 $(12 \mathrm{H}, \mathrm{brs}), 1.14-1.79(6 \mathrm{H}, \mathrm{brm}), 3.38-4.66(9 \mathrm{H}$, br m), $7.43(6 \mathrm{H}, \mathrm{br})$, 
7.72-7.87 (4H, br m); ${ }^{13} \mathrm{C}-\mathrm{NMR}(75 \mathrm{MHz}) \delta 18.87,19.03$ (each t), 19.22, 19.37 (each t), 20.89, 21.46 (each q), 22.33, 22.57 (each t), 26.65 (q), 31.49 (t), 50.26 (d), 51.13 (d), 52.65, 52.81 (each q), 63.04, 63.56 (each d), 64.90 65.37 (each t), 68.18, 69.40 (each d), 127.50 (d), 127.55 (d), 129.57 (d), 132.71 (s), 135.23 (d), 158.43, 158.79 (each s); MS m/z: $483\left(\mathrm{M}^{+}\right)$; HR-MS Calcd for $\mathrm{C}_{28} \mathrm{H}_{41} \mathrm{NO}_{4} \mathrm{Si} 483.2802$, Found 483.2822; $[\alpha]_{\mathrm{D}}^{26}+9.7^{\circ}(c=1.75$, $\mathrm{CHCl}_{3}$ ).

Methyl 6-(tert-Butyldiphenylsilyloxymethyl)-2-(3-methoxymethoxypropyl)-3-methylpiperidine-1-carboxylate (9) To a stirred solution of $\mathbf{8}$ $(785 \mathrm{mg}, 1.63 \mathrm{mmol})$ in $\mathrm{CH}_{2} \mathrm{Cl}_{2}(8 \mathrm{ml})$ were added $\mathrm{MOMCl}(0.49 \mathrm{ml}$, $6.50 \mathrm{mmol})$ and Hünig base $(1.42 \mathrm{ml}, 8.13 \mathrm{mmol})$ at $0{ }^{\circ} \mathrm{C}$, and the resulting mixture was stirred at room temperature for $45 \mathrm{~h}$. The solvent was evaporated and the residue was chromatographed on $\mathrm{SiO}_{2}(20 \mathrm{~g}$, hexane: acetone $=30: 1-15: 1)$ to afford $9(730 \mathrm{mg}, 85 \%)$ as colorless oil.

IR (neat) $2953,1695 \mathrm{~cm}^{-1} ;{ }^{1} \mathrm{H}-\mathrm{NMR}(500 \mathrm{MHz}) \delta 1.05-1.18(15 \mathrm{H}, \mathrm{br})$, $1.40-1.95(6 \mathrm{H}, \mathrm{brm}), 3.29(3 \mathrm{H}, \mathrm{br}), 3.44-4.58(8 \mathrm{H}, \mathrm{br}), 3.66(3 \mathrm{H}, \mathrm{s})$, $7.39-7.42(6 \mathrm{H}, \mathrm{br}), 7.70-7.72(4 \mathrm{H}, \mathrm{m}) ;{ }^{13} \mathrm{C}-\mathrm{NMR}(75 \mathrm{MHz}) \delta 19.24(\mathrm{q})$, 20.73, 21.08 (each t), 24.04 (t), 26.59 (t), 26.83 (q), 29.69, 30.32 (each t), 52.46 (q), 55.38 (q), 60.79 (d), 63.72, 64.96 (each t), 67.37 (t), 77.21 (d), 95.32 (t), 127.38 (d), 129.34 (d), 133.53, 133.69 (each s), 135.34 (d), 158.06 (s); MS m/z: $527\left(\mathrm{M}^{+}\right)$; HR-MS Calcd for $\mathrm{C}_{30} \mathrm{H}_{45} \mathrm{NO}_{5} \mathrm{Si}$ 527.3064, Found $527.3059 ;[\alpha]_{\mathrm{D}}^{26}-20.1^{\circ}\left(c=3.36, \mathrm{CHCl}_{3}\right)$.

Methyl 6-Hydroxymethyl-2-(3-methoxymethoxypropyl)-3-methylpiperidine-1-carboxylate (10) To a stirred solution of $9(730 \mathrm{mg}$, $1.39 \mathrm{mmol})$ in THF $(6 \mathrm{ml})$ was added a solution of TBAF $(1 \mathrm{M}$ in THF, $1.56 \mathrm{ml}, 1.56 \mathrm{mmol})$ at $0{ }^{\circ} \mathrm{C}$, and the resulting solution was stirred at room temperature for $2 \mathrm{~h}$. The reaction was quenched with satd. $\mathrm{NH}_{4} \mathrm{Cl}$ (aq.), and the aqueous mixture was extracted with $\mathrm{CHCl}_{3}(10 \mathrm{ml} \times 6)$. The organic extracts were combined, dried, and evaporated to give colorless oil, which was chromatographed on $\mathrm{SiO}_{2}(20 \mathrm{~g}$, hexane : acetone $=10: 1-2: 1)$ to afford 10 (380 mg, 95\%) as colorless oil.

IR (neat) $3475,2951,1692 \mathrm{~cm}^{-1}$; ${ }^{1} \mathrm{H}-\mathrm{NMR}(500 \mathrm{MHz}) \delta 1.03(3 \mathrm{H}, \mathrm{d}$, $J=6 \mathrm{~Hz}), 1.07-1.86(9 \mathrm{H}$, brm $), 3.35(3 \mathrm{H}, \mathrm{s}), 3.54-3.91(4 \mathrm{H}, \mathrm{brm})$, $4.04-4.23(2 \mathrm{H}, \mathrm{br}), 4.59,4.72\left(2 \mathrm{H}\right.$, each br); ${ }^{13} \mathrm{C}-\mathrm{NMR}(75 \mathrm{MHz}) \delta 18.03$ $(\mathrm{q}), 21.25(\mathrm{t}), 21.36(\mathrm{t}), 25.06(\mathrm{t}), 29.82(\mathrm{~d}), 32.07(\mathrm{t}), 52.78(\mathrm{q}), 55.87(\mathrm{q})$, $61.74(\mathrm{~d}), 65.55(\mathrm{t}), 69.19(\mathrm{t}), 76.09$ (d), $76.24(\mathrm{~d}), 95.32(\mathrm{t}), 159.71(\mathrm{~s}) ; \mathrm{MS}$ $m / z$ : $289\left(\mathrm{M}^{+}\right)$; HR-MS Calcd for $\mathrm{C}_{14} \mathrm{H}_{27} \mathrm{NO}_{5}$ 289.1888, Found 289.1869; $[\alpha]_{\mathrm{D}}^{26}-39.0^{\circ}\left(c=3.04, \mathrm{CHCl}_{3}\right)$.

Methyl 6-Hept-1-enyl-2-(3-methoxymethoxypropyl)-3-methylpiperidine-1-carboxylate (11) To a stirred solution of $(\mathrm{COCl})_{2}(0.25 \mathrm{ml}$, $1.95 \mathrm{mmol})$ in $\mathrm{CH}_{2} \mathrm{Cl}_{2}(5 \mathrm{ml})$ was added DMSO $(0.43 \mathrm{ml}, 3.90 \mathrm{mmol})$ at $-78^{\circ} \mathrm{C}$, and the resulting solution was stirred at $-78^{\circ} \mathrm{C}$ for $5 \mathrm{~min}$. To the mixture was added dropwise a solution of $\mathbf{1 0}(380 \mathrm{mg}, 1.31 \mathrm{mmol})$ in $\mathrm{CH}_{2} \mathrm{Cl}_{2}(3 \mathrm{ml})$ via a double-tipped stainless steel needle. After the reaction mixture was stirred for $30 \mathrm{~min}$ at $-78^{\circ} \mathrm{C}$, triethylamine $(1.3 \mathrm{ml}, 5.85 \mathrm{mmol})$ was added to the reaction mixture. The reaction mixture was warmed to $0^{\circ} \mathrm{C}$ for $1 \mathrm{~h}$, and quenched with $\mathrm{H}_{2} \mathrm{O}$. The aqueous mixture was extracted with $\mathrm{Et}_{2} \mathrm{O}(10 \mathrm{ml} \times 3)$. The organic extracts were combined, dried, and evaporated to give pale yellow oil, which was used directly in the next step.

To a stirred suspension of hexyltriphenylphsphoniumbromide $(2.8 \mathrm{~g}$, $6.56 \mathrm{mmol})$ in THF $(10 \mathrm{ml})$ was added a solution of $n-\mathrm{BuLi}(1.6 \mathrm{M}$ in hexane, $3.7 \mathrm{ml}, 5.92 \mathrm{mmol}$ ) at $0^{\circ} \mathrm{C}$, and the resulting orange solution was stirred for $10 \mathrm{~min}$ at $0^{\circ} \mathrm{C}$. To the mixture was added dropwise a solution of the above aldehyde in THF $(4 \mathrm{ml})$ via a double-tipped stainless steel needle. After the reaction mixture was stirred for $14 \mathrm{~h}$ at room temperature, the reaction was quenched with $\mathrm{H}_{2} \mathrm{O}$. The aqueous mixture was extracted with $\mathrm{Et}_{2} \mathrm{O}$ $(10 \mathrm{ml} \times 3)$, and the organic extracts were combined, dried, and evaporated to give pale yellow oil, which was chromatographed on $\mathrm{SiO}_{2}(20 \mathrm{~g}$, hexane : acetone $=100: 1-15: 1)$ to afford $11(310 \mathrm{mg}, 66 \%)$ as pale yellow oil.

IR (neat) 2953, $1694 \mathrm{~cm}^{-1} ;{ }^{1} \mathrm{H}-\mathrm{NMR}(500 \mathrm{MHz}) \delta 0.86-0.93(6 \mathrm{H}, \mathrm{m})$, $1.02-1.43(10 \mathrm{H}$, br m) $, 1.53-2.18(7 \mathrm{H}$, br m $), 3.36(3 \mathrm{H}, \mathrm{s}), 3.67(3 \mathrm{H}, \mathrm{s})$ $3.65-3.79(2 \mathrm{H}, \mathrm{br}), 3.90(1 \mathrm{H}, \mathrm{br}), 4.60(2 \mathrm{H}, \mathrm{s}), 4.83(1 \mathrm{H}, \mathrm{br}), 5.38(1 \mathrm{H}, \mathrm{m})$, $5.68(1 \mathrm{H}, \mathrm{m}) ; \mathrm{MS} m / z: 355\left(\mathrm{M}^{+}\right)$

5-Heptyl-8-methyloctahydroindolizine (Indolizidine 237D, 2) To а stirred solution of $\mathbf{1 1}(200 \mathrm{mg}, 0.56 \mathrm{mmol})$ in EtOAc $(10 \mathrm{ml})$ was added $10 \%$ $\mathrm{Pd}-\mathrm{C}(30 \mathrm{mg})$, and the resulting suspension was hydrogenated under hydrogen atmosphere at $1 \mathrm{~atm}$ for $48 \mathrm{~h}$. The catalyst was removed by filtration and the filtrate was evaporated to give colorless oil, which was used directly in the next step.

To a stirred solution of $n$-PrSH $(0.51 \mathrm{ml}, 5.63 \mathrm{mmol})$ in HMPA $(2.5 \mathrm{ml})$ was added a solution of $n$-BuLi $(1.6 \mathrm{M}$ in hexane, $3.3 \mathrm{ml}, 5.35 \mathrm{mmol})$ at $0{ }^{\circ} \mathrm{C}$, and the reaction mixture was stirred at $0{ }^{\circ} \mathrm{C}$ for $30 \mathrm{~min}$. To the reaction mixture was added dropwise a solution of the above oil in THF $(3 \mathrm{ml})$ via a dou- ble-tipped stainless needle. The reaction was stirred at room temperature for $54 \mathrm{~h}$, and quenched with $28 \% \mathrm{NH}_{3}$ (aq.). The aqueous mixture was extracted with $\mathrm{Et}_{2} \mathrm{O}(10 \mathrm{ml} \times 10)$, and the organic extracts were combined, dried over $\mathrm{K}_{2} \mathrm{CO}_{3}$, and evaporated to give pale yellow oil, which was used directly in the next step.

To a solution of the above oil in $\mathrm{MeOH}(5 \mathrm{ml})$ was added conc. $\mathrm{HCl}(8$ drops), and the reaction mixture was heated at reflux for $1 \mathrm{~h}$. After cooling, the solvent was evaporated, and the residue was washed with $\mathrm{Et}_{2} \mathrm{O}$. To the residue was added $28 \% \mathrm{NH}_{3}$ (aq.), and the aqueous mixture was extracted with $\mathrm{CHCl}_{3}(10 \mathrm{ml} \times 10)$. The organic extracts were combined, dried over $\mathrm{K}_{2} \mathrm{CO}_{3}$, and evaporated to give pale yellow oil, which was used directly in the next step.

To a stirred solution of the above oil in $\mathrm{CH}_{2} \mathrm{Cl}_{2}(5 \mathrm{ml})$ were added $\mathrm{CBr}_{4}$ $(262 \mathrm{mg}, 0.79 \mathrm{mmol})$ and $\mathrm{Ph}_{3} \mathrm{P}(221 \mathrm{mg}, 0.85 \mathrm{mmol})$ at $0{ }^{\circ} \mathrm{C}$, and the resulting mixture was stirred at $0^{\circ} \mathrm{C}$ for $1 \mathrm{~h}$. To the reaction mixture was added triethylamine $(1.25 \mathrm{ml}, 9.01 \mathrm{mmol})$, and the stirring was continued for $30 \mathrm{~min}$ at room temperature. The volatiles were removed, and the residue was extracted with pentane $(5 \mathrm{ml} \times 4)$. The solvent was evaporated to give pale orange solid, which was chromatographed on $\mathrm{SiO}_{2}(20 \mathrm{~g}$, hexane : acetone $=20: 1)$ to afford $2(56 \mathrm{mg}, 42 \%)$ as pale yellow oil.

Determination of absolute stereochemistry of natural 237D was as follows: Both (+)- and (-)-237D were prepared by the catalytic hydrogenation of natural $(+)-235 \mathrm{~B}$, isolated from $D$. pumilio or $(-)-235 \mathrm{~B}$, present in an extract of D. speciosus. Gas chromatography using flame-ionization detection and a chiral column, permethylated $\beta$-cycldextrin (SGE, $30 \mathrm{~m} \times$ $0.25 \mathrm{~mm} ; 130^{\circ} \mathrm{C}$ at $0.5^{\circ} \mathrm{C} / \mathrm{min}$ ), resulted in a baseline separation of $(+)$ - and $(-)-237 \mathrm{D}$ as previously reported. The retention times were 31.9 and 32.4 min respectively. Natural 237D present in D. pumilio or D. speciosus was co-chromatographed with $(-)-7$ on the chiral column using the above conditions. The synthetic (-)-7 and (-)-7, prepared from the hydrogenation of $235 \mathrm{~B}$, were co-chromatographed on GC-MS with a non-chiral column (Zebron-5 (Phenomenex) $100-280^{\circ} \mathrm{C}$ at $5^{\circ} \mathrm{C} / \mathrm{min}$ ) and had identical GCEI-MS and GC-FT-IR spectra providing that they had the same relative and absolute stereochemistry.

IR (neat) 2926, 2855, 2777, 1457, 1376, 1164, 1131, 908, 733, $640 \mathrm{~cm}^{-1}$. ${ }^{1} \mathrm{H}-\mathrm{NMR}(500 \mathrm{MHz}) \delta 0.88(3 \mathrm{H}, \mathrm{d}, J=6.8 \mathrm{~Hz}), 0.89(3 \mathrm{H}, \mathrm{t}, J=6.8 \mathrm{~Hz}), 0.97$ $(1 \mathrm{H}, \mathrm{q}-\mathrm{like}, J=11.5 \mathrm{~Hz}), 1.27-1.38(13 \mathrm{H}, \mathrm{br} \mathrm{m}), 1.51-2.18(10 \mathrm{H}, \mathrm{br} \mathrm{m})$, $3.31(1 \mathrm{H}, \mathrm{br}) ;{ }^{13} \mathrm{C}-\mathrm{NMR}(75 \mathrm{MHz}) \delta 14.16(\mathrm{q}), 18.93(\mathrm{q}), 20.36(\mathrm{t}), 22.72$ $(\mathrm{t}), 25.89(\mathrm{t}), 29.03(\mathrm{t}), 29.32(\mathrm{t}), 30.05(\mathrm{t}), 31.15(\mathrm{t}), 31.88(\mathrm{t}), 33.67(\mathrm{t})$, $34.53(\mathrm{t}), 36.44(\mathrm{~d}), 51.78(\mathrm{t}), 63.60$ (d), 71.37 (d); MS m/z: $237\left(\mathrm{M}^{+}\right)$; HRMS Calcd for $\mathrm{C}_{16} \mathrm{H}_{31} \mathrm{~N}$ 237.2455, Found 237.2452; $[\alpha]_{\mathrm{D}}^{26}-98.9^{\circ}(c=1.59$, $\mathrm{CHCl}_{3}$ ).

Methyl 6-[4-(tert-Butyldiphenylsilyloxy)but-1-enyl]-2-(3-methoxymethoxypropyl)-3-methylpiperidine-1-carboxylate (12) To a stirred solution of $(\mathrm{COCl})_{2}(0.32 \mathrm{ml}, 3.63 \mathrm{mmol})$ in $\mathrm{CH}_{2} \mathrm{Cl}_{2}(10 \mathrm{ml})$ was added DMSO $(0.52 \mathrm{ml}, 7.27 \mathrm{mmol})$ at $-78^{\circ} \mathrm{C}$, and the resulting solution was stirred at $-78^{\circ} \mathrm{C}$ for $5 \mathrm{~min}$. To the mixture was added dropwise a solution of $\mathbf{1 0}$ (700 mg, $2.42 \mathrm{mmol})$ in $\mathrm{CH}_{2} \mathrm{Cl}_{2}(6 \mathrm{ml})$ via a double-tipped stainless steel needle. After the reaction mixture was stirred for $30 \mathrm{~min}$ at $-78^{\circ} \mathrm{C}$, triethylamine $(1.5 \mathrm{ml}, 10.90 \mathrm{mmol})$ was added to the reaction mixture. The reaction mixture was warmed to $0^{\circ} \mathrm{C}$ for $1 \mathrm{~h}$, and quenched with $\mathrm{H}_{2} \mathrm{O}$. The aqueous mixture was extracted with $\mathrm{Et}_{2} \mathrm{O}(15 \mathrm{ml} \times 3)$. The organic extracts were combined, dried, and evaporated to give pale yellow oil, which was used directly in the next step.

To a stirred suspension of TBDPSO $\left(\mathrm{CH}_{2}\right)_{3} \mathrm{P}^{+} \mathrm{Ph}_{3} \mathrm{Br}^{-}(6.96 \mathrm{~g}, 10.90 \mathrm{mmol})$ in THF $(18 \mathrm{ml})$ was added a solution of $n$-BuLi $(1.6 \mathrm{M}$ in hexane, $6 \mathrm{ml}$, $9.69 \mathrm{mmol}$ ) at $0{ }^{\circ} \mathrm{C}$, and the resulting orange solution was stirred at $0{ }^{\circ} \mathrm{C}$ for $10 \mathrm{~min}$. To the mixture was added dropwise a solution of the above aldehyde in THF ( $4 \mathrm{ml})$ via a double-tipped stainless needle. The reaction was stirred at room temperature for $21 \mathrm{~h}$, and quenched with $\mathrm{H}_{2} \mathrm{O}$. The aqueous mixture was extracted with $\mathrm{Et}_{2} \mathrm{O}(15 \mathrm{ml} \times 3)$. The organic extracts were combined, dried, and evaporated to give pale yellow oil, which was chromatographed on $\mathrm{SiO}_{2}(40 \mathrm{~g}$, hexane : acetone $=100: 1-40: 1)$ to afford $12(1.19 \mathrm{~g}, 87 \%)$ as pale yellow oil.

IR (neat) 2956, $1691 \mathrm{~cm}^{-1}$; ${ }^{1} \mathrm{H}-\mathrm{NMR} \quad(500 \mathrm{MHz}) \delta 1.03 \quad(3 \mathrm{H}, \mathrm{d}$, $J=7.4 \mathrm{~Hz}), 1.06(9 \mathrm{H}, \mathrm{s}), 1.18-1.24(1 \mathrm{H}, \mathrm{m}), 1.28-1.30(1 \mathrm{H}, \mathrm{m}), 1.56$ $1.93(7 \mathrm{H}$, br m), $2.38-2.42(1 \mathrm{H}, \mathrm{m}), 2.52-2.55(1 \mathrm{H}, \mathrm{m}), 3.37(3 \mathrm{H}, \mathrm{s})$, $3.52-3.59(2 \mathrm{H}, \mathrm{m}), 3.63(3 \mathrm{H}, \mathrm{s}), 3.62-3.73(2 \mathrm{H}, \mathrm{m}), 3.92,4.06(1 \mathrm{H}$, each br), $4.61(2 \mathrm{H}, \mathrm{s}), 4.87-4.92(1 \mathrm{H}, \mathrm{br}), 5.46-5.50(1 \mathrm{H}, \mathrm{m}), 5.61-5.68(1 \mathrm{H}$, m), 7.37-7.45 (6H, m), 7.67-7.74 (4H, m); MS m/z: $567\left(\mathrm{M}^{+}\right)$

Methyl 6-(4-Hydroxybutyl)-2-(3-methoxymethoxypropyl)-3-methylpiperidine-1-carboxylate (13) To a stirred solution of $\mathbf{1 2}(1.08 \mathrm{~g}$, $1.90 \mathrm{mmol})$ in EtOAc $(20 \mathrm{ml})$ was added $10 \% \mathrm{Pd}-\mathrm{C}(100 \mathrm{mg})$, and the resulting suspension was hydrogenated under hydrogen atmosphere at $1 \mathrm{~atm}$ 
for $48 \mathrm{~h}$. The catalyst was removed by filtration and the filtrate was evaporated to give colorless oil, which was used directly in the next step.

To a stirred solution of the above oil in THF $(8 \mathrm{ml})$ was added a solution of TBAF ( $1 \mathrm{M}$ in THF, $2.1 \mathrm{ml}, 2.1 \mathrm{mmol})$ at $0{ }^{\circ} \mathrm{C}$, and the mixture was stirred at room temperature for $2 \mathrm{~h}$. The reaction was quenched with satd. $\mathrm{NH}_{4} \mathrm{Cl}$ (aq.), and the aqueous mixture was extracted with $\mathrm{CHCl}_{3}(10 \mathrm{ml} \times 7)$. The organic extracts were combined, dried, and evaporated to give colorless oil, which was chromatographed on $\mathrm{SiO}_{2}(20 \mathrm{~g}$, hexane : acetone $=15: 1-2: 1)$ to afford $13(548 \mathrm{mg}, 87 \%)$ as colorless oil.

IR (neat) $3442,2941,1672 \mathrm{~cm}^{-1}$; ${ }^{1} \mathrm{H}-\mathrm{NMR}(500 \mathrm{MHz}) \delta 0.91-0.93(3 \mathrm{H}$, br), $1.09-1.87(15 \mathrm{H}, \mathrm{br} \mathrm{m}), 2.86(1 \mathrm{H}, \mathrm{br}), 3.27(3 \mathrm{H}, \mathrm{s}), 3.43(2 \mathrm{H}, \mathrm{br} \mathrm{s}), 3.50$ $(2 \mathrm{H}$, brs $), 3.58(3 \mathrm{H}, \mathrm{s}), 3.72-4.02(2 \mathrm{H}, \mathrm{br}), 4.52(2 \mathrm{H}, \mathrm{s}) ;{ }^{13} \mathrm{C}-\mathrm{NMR}$ $(75 \mathrm{MHz}) \delta 18.88(\mathrm{q}), 19.21(\mathrm{t}), 21.55(\mathrm{t}), 22.02(\mathrm{t}), 23.20(\mathrm{t}), 27.33(\mathrm{t})$, $30.63(d), 32.30(t), 32.83(t), 34.87$ (t), 50.63 (d), 52.25 (q), 54.87 (d), 56.52 (d), $62.10(\mathrm{t}), 67.36(\mathrm{t}), 96.03(\mathrm{t}), 157.27(\mathrm{~s}) ; \mathrm{MS} m / z: 331\left(\mathrm{M}^{+}\right)$; HR-MS Calcd for $\mathrm{C}_{17} \mathrm{H}_{33} \mathrm{NO}_{5} 331.2357$, Found 331.2370; $[\alpha]_{\mathrm{D}}^{26}-11.2^{\circ}(c=0.82$, $\mathrm{CHCl}_{3}$ ).

Methyl 2-(3-Methoxymethoxypropyl)-3-methyl-6-pent-4-enylpiperidine-1-carboxylate (14) To a stirred solution of $(\mathrm{COCl})_{2} \quad(0.1 \mathrm{ml}$, $1.15 \mathrm{mmol})$ in $\mathrm{CH}_{2} \mathrm{Cl}_{2}(2 \mathrm{ml})$ was added DMSO $(0.17 \mathrm{ml}, 2.30 \mathrm{mmol})$ at $-78^{\circ} \mathrm{C}$, and the resulting solution was stirred at $-78^{\circ} \mathrm{C}$ for $5 \mathrm{~min}$. To the mixture was added dropwise a solution of $\mathbf{1 3}(150 \mathrm{mg}, 0.45 \mathrm{mmol})$ in $\mathrm{CH}_{2} \mathrm{Cl}_{2}(2 \mathrm{ml})$ via a double-tipped stainless steel needle. After the reaction mixture was stirred for $30 \mathrm{~min}$ at $-78^{\circ} \mathrm{C}$, triethylamine $(0.5 \mathrm{ml}, 3.45 \mathrm{mmol})$ was added to the reaction mixture. The reaction mixture was warmed to $0{ }^{\circ} \mathrm{C}$ for $1 \mathrm{~h}$, and quenched with $\mathrm{H}_{2} \mathrm{O}$. The aqueous mixture was extracted with $\mathrm{Et}_{2} \mathrm{O}(10 \mathrm{ml} \times 3)$. The organic extracts were combined, dried, and evaporated to give pale yellow oil, which was used directly in the next step.

To a stirred suspension of $\mathrm{MeP}^{+} \mathrm{Ph}_{3} \mathrm{I}^{-}(915 \mathrm{mg}, 2.27 \mathrm{mmol})$ in THF $(8 \mathrm{ml})$ was added a solution of $n$-BuLi $(1.6 \mathrm{M}$ in hexane, $1.27 \mathrm{ml}, 2.04 \mathrm{mmol})$ at $0{ }^{\circ} \mathrm{C}$, and the resulting orange solution was stirred at $0{ }^{\circ} \mathrm{C}$ for $10 \mathrm{~min}$. To the mixture was added dropwise a solution of the above aldehyde in THF $(4 \mathrm{ml})$ via a double-tipped stainless needle. The reaction was stirred at room temperature for $17 \mathrm{~h}$, and quenched with $\mathrm{H}_{2} \mathrm{O}$. The aqueous mixture was extracted with $\mathrm{Et}_{2} \mathrm{O}(15 \mathrm{ml} \times 3)$. The organic extracts were combined, dried, and evaporated to give pale yellow oil, which was chromatographed on $\mathrm{SiO}_{2}$ $(20 \mathrm{~g}$, hexane $:$ acetone $=100: 1-20: 1)$ to afford $14(132 \mathrm{mg}, 89 \%)$ as pale yellow oil.

IR (neat) $3071,2940,1694 \mathrm{~cm}^{-1} ;{ }^{1} \mathrm{H}-\mathrm{NMR}(500 \mathrm{MHz}) \delta 1.00(3, \mathrm{~d}$, $J=7 \mathrm{~Hz}), 1.12-1.19(1 \mathrm{H}, \mathrm{m}), 1.30-1.44(3 \mathrm{H}, \mathrm{m}), 1.45-1.63(5 \mathrm{H}, \mathrm{br} \mathrm{m})$, $1.71-1.89(4 \mathrm{H}, \mathrm{m}), 1.98-2.09(2 \mathrm{H}, \mathrm{m}), 3.34(3 \mathrm{H}, \mathrm{s}), 3.47-3.55(2 \mathrm{H}, \mathrm{m})$, $3.66(3 \mathrm{H}, \mathrm{s}), 3.72-3.92(1 \mathrm{H}, \mathrm{br}), 4.03-4.13(1 \mathrm{H}, \mathrm{br}), 4.60(2 \mathrm{H}, \mathrm{s}), 4.93$ $(1 \mathrm{H}$, dq-like, $J=9.9,1 \mathrm{~Hz}), 4.98(1 \mathrm{H}$, dq-like, $J=16.1,1.7 \mathrm{~Hz}), 5.78(1 \mathrm{H}$, ddt, $J=16.1,9.9,6.5 \mathrm{~Hz}) ;{ }^{13} \mathrm{C}-\mathrm{NMR}(75 \mathrm{MHz}) \delta 19.32(\mathrm{q}), 21.67(\mathrm{t}), 22.18$ $(\mathrm{t}), 26.46(\mathrm{t}), 27.48(\mathrm{t}), 30.72(\mathrm{~d}), 32.94(\mathrm{t}), 33.61(\mathrm{t}), 34.83(\mathrm{t}), 50.76(\mathrm{~d})$, $52.38(\mathrm{q}), 55.07(\mathrm{q}), 56.66(\mathrm{~d}), 67.57(\mathrm{t}), 96.32(\mathrm{t}), 114.48(\mathrm{t}), 138.68(\mathrm{~d})$, $157.57(\mathrm{~s})$; MS $\mathrm{m} / \mathrm{z}$ : $327\left(\mathrm{M}^{+}\right)$; HR-MS Calcd for $\mathrm{C}_{18} \mathrm{H}_{33} \mathrm{NO}_{4} 327.2408$, Found 327.2441; $[\alpha]_{\mathrm{D}}^{26}-10.9^{\circ}\left(c=0.95, \mathrm{CHCl}_{3}\right)$.

8-Methyl-5-pent-4-enyloctahydro-indolizine (Indolizidine 207A，3) To a stirred solution of $n$-PrSH $(0.38 \mathrm{ml}, 4.20 \mathrm{mmol})$ in HMPA $(2.5 \mathrm{ml})$ was added a solution of $n$-BuLi $(1.6 \mathrm{M}$ in hexane, $2.5 \mathrm{ml}, 4.02 \mathrm{mmol})$ at $0{ }^{\circ} \mathrm{C}$, and the reaction mixture was stirred at $0^{\circ} \mathrm{C}$ for $30 \mathrm{~min}$. To the reaction mixture was added dropwise a solution of $\mathbf{1 4}(138 \mathrm{mg}, 0.42 \mathrm{mmol})$ in THF (3 ml) via a double-tipped stainless needle. The reaction was stirred at room temperature for $49 \mathrm{~h}$, and quenched with $28 \% \mathrm{NH}_{3}$ (aq.). The aqueous mixture was extracted with $\mathrm{Et}_{2} \mathrm{O}(10 \mathrm{ml} \times 10)$, and the organic extracts were combined, dried over $\mathrm{K}_{2} \mathrm{CO}_{3}$, and evaporated to give pale yellow oil, which was used directly in the next step.

To a solution of the above oil in $\mathrm{MeOH}(5 \mathrm{ml})$ was added conc. $\mathrm{HCl}(5$ drops), and the reaction mixture was heated at reflux for $1 \mathrm{~h}$. After cooling, the solvent was evaporated, and the residue was washed with $\mathrm{Et}_{2} \mathrm{O}$. To the residue was added $28 \% \mathrm{NH}_{3}$ (aq.), and the aqueous mixture was extracted with $\mathrm{CHCl}_{3}(10 \mathrm{ml} \times 10)$. The organic extracts were combined, dried over $\mathrm{K}_{2} \mathrm{CO}_{3}$, and evaporated to give pale yellow oil, which was used directly in the next step.

To a stirred solution of the above oil in $\mathrm{CH}_{2} \mathrm{Cl}_{2}(7 \mathrm{ml})$ were added $\mathrm{CBr}_{4}$ $(195 \mathrm{mg}, 0.59 \mathrm{mmol})$ and $\mathrm{Ph}_{3} \mathrm{P}(166 \mathrm{mg}, 0.63 \mathrm{mmol})$ at $0{ }^{\circ} \mathrm{C}$, and the resulting mixture was stirred at $0{ }^{\circ} \mathrm{C}$ for $1 \mathrm{~h}$. To the reaction mixture was added triethylamine $(0.9 \mathrm{ml}, 6.47 \mathrm{mmol})$, and the stirring was continued for $30 \mathrm{~min}$ at room temperature. The volatiles were removed, and the residue was extracted with pentane $(5 \mathrm{ml} \times 4)$. The solvent was evaporated to give pale orange solid, which was chromatographed on $\mathrm{SiO}_{2}(20 \mathrm{~g}$, hexane : acetone $=$ $20: 1)$ to afford $3(55 \mathrm{mg}, 63 \%)$ as pale yellow oil.

IR (neat) $3074,2933,2872,2775,2701,1642,1455,1336,1242,1165$,
$1088,909 \mathrm{~cm}^{-1} ;{ }^{1} \mathrm{H}-\mathrm{NMR}(500 \mathrm{MHz}) \delta 0.86(3 \mathrm{H}, \mathrm{d}, J=6.4 \mathrm{~Hz}), 0.98(1 \mathrm{H}$, qd-like, $J=14.1,4.7 \mathrm{~Hz}), 1.20-2.09(17 \mathrm{H}$, br m $), 3.26(1 \mathrm{H}, \mathrm{t}$-like, $J=8.7 \mathrm{~Hz}), 4.93(1 \mathrm{H}, \mathrm{dd}, J=10.1,2.2 \mathrm{~Hz}), 4.99(1 \mathrm{H}, \mathrm{dd}, J=17.1,2.2 \mathrm{~Hz})$, 5.76-5.84 (1H, m); ${ }^{13} \mathrm{C}-\mathrm{NMR}(75 \mathrm{MHz}) \delta 18.96(\mathrm{q}), 20.42(\mathrm{t}), 25.21(\mathrm{t})$, $29.13(\mathrm{t}), 31.29(\mathrm{t}), 33.72(\mathrm{t}), 34.12(\mathrm{t}), 34.16(\mathrm{t}), 36.60(\mathrm{~d}), 51.87(\mathrm{t}), 63.36$ (d), $71.32(\mathrm{~d}), 114.31(\mathrm{t}), 138.69$ (d); $\mathrm{MS} m / z: 207\left(\mathrm{M}^{+}\right) ;[\alpha]_{\mathrm{D}}^{26}-86.7^{\circ}$ $\left(c=2.64, \mathrm{CHCl}_{3}\right) ;$ lit. $^{13)}[\alpha]_{\mathrm{D}}^{28}-86.5^{\circ}\left(c=0.95, \mathrm{CHCl}_{3}\right) ;$ lit. $^{14)}[\alpha]_{\mathrm{D}}^{22.5}$ $-103.2^{\circ}\left(c=0.47, \mathrm{CHCl}_{3}\right)$.

Methyl 6-(4-Iodobutyl)-2-(3-methoxymethoxypropyl)-3-methylpiperidine-1-carboxylate (15) To a stirred solution of $13(257 \mathrm{mg}, 0.78 \mathrm{mmol})$ in $\mathrm{CH}_{2} \mathrm{Cl}_{2}(3 \mathrm{ml})$ were added triethylamine $(0.41 \mathrm{ml}, 2.95 \mathrm{mmol})$ and $\mathrm{MsCl}$ $(0.17 \mathrm{ml}, 2.18 \mathrm{mmol})$ at $0{ }^{\circ} \mathrm{C}$, and the reaction mixture was stirred at $0{ }^{\circ} \mathrm{C}$ for $30 \mathrm{~min}$. The reaction was quenched with satd. $\mathrm{NaHCO}_{3}$ (aq.), and the aqueous mixture was extracted with $\mathrm{CH}_{2} \mathrm{Cl}_{2}(10 \mathrm{ml} \times 3)$. The organic extracts were combined, dried, and evaporated to give pale yellow oil, which was used directly in the next step.

To a stirred solution of the above oil in acetone $(10 \mathrm{ml})$ was added $\mathrm{NaI}$ $(582 \mathrm{mg}, 3.88 \mathrm{mmol})$, and the resulting mixture was heated at $50^{\circ} \mathrm{C}$ for $2 \mathrm{~h}$. After cooling, the reaction was quenched with $10 \% \mathrm{Na}_{2} \mathrm{~S}_{2} \mathrm{O}_{3}$ in satd. $\mathrm{NaHCO}_{3}$ (aq.), and the aqueous mixture was extracted with $\mathrm{CH}_{2} \mathrm{Cl}_{2}$ $(15 \mathrm{ml} \times 3)$. The organic extracts were combined, dried, and evaporated to give pale yellow oil, which was chromatographed on $\mathrm{SiO}_{2}(20 \mathrm{~g}$, hexane : acetone $=30: 1)$ to afford $\mathbf{1 5}(330 \mathrm{mg}, 96 \%)$ as colorless oil.

IR (neat) 2944, $1701 \mathrm{~cm}^{-1}$; ${ }^{1} \mathrm{H}-\mathrm{NMR}(500 \mathrm{MHz}) \delta 0.99(3 \mathrm{H}, \mathrm{d}$, $J=7.2 \mathrm{~Hz}), 1.15-1.17(1 \mathrm{H}, \mathrm{m}), 1.32-1.89(14 \mathrm{H}, \mathrm{br} \mathrm{m}), 3.17(2 \mathrm{H}, \mathrm{t}$-like, $J=6.9 \mathrm{~Hz}), 3.34(3 \mathrm{H}, \mathrm{s}), 3.49-3.52(2 \mathrm{H}, \mathrm{m}), 3.66(3 \mathrm{H}, \mathrm{s}), 3.80(1 \mathrm{H}, \mathrm{br})$, $4.08(1 \mathrm{H}, \mathrm{br}), 4.60(2 \mathrm{H}, \mathrm{s}) ;{ }^{13} \mathrm{C}-\mathrm{NMR}(75 \mathrm{MHz}) \delta 6.94(\mathrm{t}), 19.42(\mathrm{q}), 21.76$ $(t), 22.20(t), 27.52(t), 28.01(t), 30.78(d), 33.09(t), 33.19(t), 34.14(t)$, $50.53(\mathrm{~d}), 52.42(\mathrm{q}), 55.09(\mathrm{q}), 56.65(\mathrm{~d}), 67.52(\mathrm{t}), 96.27(\mathrm{t}), 157.28(\mathrm{~s}) ; \mathrm{MS}$ $m / z$ : $441\left(\mathrm{M}^{+}\right)$; HR-MS Calcd for $\mathrm{C}_{17} \mathrm{H}_{32} \mathrm{INO}_{4} 441.1375$, Found 441.1387; $[\alpha]_{\mathrm{D}}^{26}-8.60^{\circ}\left(c=5.31, \mathrm{CHCl}_{3}\right)$.

Methyl 2-(3-Methoxymethoxypropyl)-3-methyl-6-oct-7-enylpiperidine-1-carboxylate (16) To a stirred suspension of $\mathrm{CuI}(501 \mathrm{mg}$, $2.63 \mathrm{mmol})$ in THF $(5 \mathrm{ml})$ was added a solution 1-butenylmagnesium bromide in THF (prepared from 4-bromo-1-butene $(0.53 \mathrm{ml}, 5.26 \mathrm{mmol})$ and magnesium $(126 \mathrm{mg}, 5.26 \mathrm{mmol})$ in THF $(3 \mathrm{ml})$, reflux) at $-40^{\circ} \mathrm{C}$, and the reaction was stirred at $-40-35^{\circ} \mathrm{C}$ for $15 \mathrm{~min}$. To the reaction mixture was added $15(290 \mathrm{mg}, 0.66 \mathrm{mmol})$ in THF $(4 \mathrm{ml})$ at the same temperature, and the stirring was continued for $5 \mathrm{~h}$. The reaction was quenched with satd. $\mathrm{NH}_{4} \mathrm{Cl}$ (aq.), and the insoluble materials were filtered off. The filtrate was extracted with $\mathrm{CH}_{2} \mathrm{Cl}_{2}(15 \mathrm{ml} \times 4)$. The organic extracts were combined, dried, and evaporated to give pale yellow oil, which was chromatographed on $\mathrm{SiO}_{2}(20 \mathrm{~g}$, hexane $:$ acetone $=50: 1-20: 1)$ to afford $16(220 \mathrm{mg}, 91 \%)$ as colorless oil.

IR (neat) $3073,2941,1696 \mathrm{~cm}^{-1}$; ${ }^{1} \mathrm{H}-\mathrm{NMR}(500 \mathrm{MHz}) \delta 0.97(3 \mathrm{H}, \mathrm{d}$, $J=6.8 \mathrm{~Hz}), 1.11-1.58(16 \mathrm{H}, \mathrm{br} \mathrm{m}), 1.72-1.84(3 \mathrm{H}, \mathrm{m}), 1.97-2.00(2 \mathrm{H}$, $\mathrm{m}), 3.31(3 \mathrm{H}, \mathrm{s}), 3.45-3.51(2 \mathrm{H}, \mathrm{m}), 3.63(3 \mathrm{H}, \mathrm{s}), 3.80(1 \mathrm{H}, \mathrm{br}), 4.04(1 \mathrm{H}$, br), $4.56(2 \mathrm{H}, \mathrm{s}), 4.88(1 \mathrm{H}, \mathrm{dm}, J=9.8 \mathrm{~Hz}), 4.94(1 \mathrm{H}, \mathrm{dm}, J=17 \mathrm{~Hz}), 5.71-$ $5.80(1 \mathrm{H}, \mathrm{m}) ;{ }^{13} \mathrm{C}-\mathrm{NMR}(75 \mathrm{MHz}) \delta 19.35(\mathrm{q}), 21.73(\mathrm{t}), 22.12(\mathrm{t}), 27.15(\mathrm{t})$, $27.47(\mathrm{t}), 28.83(\mathrm{t}), 29.03(\mathrm{t}), 29.37(\mathrm{t}), 30.78(\mathrm{~d}), 32.96(\mathrm{t}), 33.70(\mathrm{t}), 35.34$ (t), $50.84(\mathrm{~d}), 52.25(\mathrm{q}), 54.96(\mathrm{q}), 56.58(\mathrm{~d}), 67.47(\mathrm{t}), 96.16(\mathrm{t}), 113.95(\mathrm{t})$, 138.82 (d), 157.27 (s); MS m/z: $369\left(\mathrm{M}^{+}\right)$; HR-MS Calcd for $\mathrm{C}_{21} \mathrm{H}_{39} \mathrm{NO}_{4}$ 369.2877 , Found 369.2871; $[\alpha]_{\mathrm{D}}^{26}-5.20^{\circ}\left(c=11.0, \mathrm{CHCl}_{3}\right)$.

8-Methyl-5-oct-7-enyloctahydroindolizine (5) To a stirred solution of $n$-PrSH $(0.55 \mathrm{ml}, 5.99 \mathrm{mmol})$ in HMPA $(4 \mathrm{ml})$ was added a solution of $n$ $\operatorname{BuLi}(1.6 \mathrm{M}$ in hexane, $3.6 \mathrm{ml}, 5.77 \mathrm{mmol})$ at $0{ }^{\circ} \mathrm{C}$, and the reaction mixture was stirred at $0{ }^{\circ} \mathrm{C}$ for $30 \mathrm{~min}$. To the reaction mixture was added dropwise a solution of $16(220 \mathrm{mg}, 0.60 \mathrm{mmol})$ in THF $(6 \mathrm{ml})$ via a double-tipped stainless needle. The reaction was stirred at room temperature for $49 \mathrm{~h}$, and quenched with $28 \% \mathrm{NH}_{3}$ (aq.). The aqueous mixture was extracted with $\mathrm{Et}_{2} \mathrm{O}(10 \mathrm{ml} \times 10)$, and the organic extracts were combined, dried over $\mathrm{K}_{2} \mathrm{CO}_{3}$, and evaporated to give pale yellow oil, which was used directly in the next step.

To a solution of the above oil in $\mathrm{MeOH}(15 \mathrm{ml})$ was added conc. $\mathrm{HCl}(10$ drops), and the reaction mixture was heated at reflux for $1 \mathrm{~h}$. After cooling, the solvent was evaporated, and the residue was washed with $\mathrm{Et}_{2} \mathrm{O}$. To the residue was added $28 \% \mathrm{NH}_{3}$ (aq.), and the aqueous mixture was extracted with $\mathrm{CHCl}_{3}(10 \mathrm{ml} \times 10)$. The organic extracts were combined, dried over $\mathrm{K}_{2} \mathrm{CO}_{3}$, and evaporated to give pale yellow oil, which was used directly in the next step.

To a stirred solution of the above oil in $\mathrm{CH}_{2} \mathrm{Cl}_{2}(10 \mathrm{ml})$ were added $\mathrm{CBr}_{4}$ $(280 \mathrm{mg}, 0.84 \mathrm{mmol})$ and $\mathrm{Ph}_{3} \mathrm{P}(237 \mathrm{mg}, 0.90 \mathrm{mmol})$ at $0{ }^{\circ} \mathrm{C}$, and the resulting mixture was stirred at $0^{\circ} \mathrm{C}$ for $1 \mathrm{~h}$. To the reaction mixture was added triethylamine $(1.33 \mathrm{ml}, 9.66 \mathrm{mmol})$, and the stirring was continued for 
$30 \mathrm{~min}$ at room temperature. The volatiles were removed, and the residue was extracted with pentane $(10 \mathrm{ml} \times 4)$. The solvent was evaporated to give pale orange solid, which was chromatographed on $\mathrm{SiO}_{2}(20 \mathrm{~g}$, hexane : acetone $=20: 1)$ to afford $5(83 \mathrm{mg}, 56 \%)$ as pale yellow oil.

IR (neat) $3077,2936,2870,2779,2702,1640,1455,1332,1243,1166$ 1133, 1109, 992, $907 \mathrm{~cm}^{-1}$; ${ }^{1} \mathrm{H}-\mathrm{NMR}(500 \mathrm{MHz}) \delta 0.85(3 \mathrm{H}, \mathrm{d}, J=6.4 \mathrm{~Hz})$, $0.87-0.98(1 \mathrm{H}, \mathrm{m}), 1.17-1.54(13 \mathrm{H}$, br m) $1.58-1.66(2 \mathrm{H}, \mathrm{m}), 1.70-$ $1.85(3 \mathrm{H}$, br m), $1.84(1 \mathrm{H}, \mathrm{m}), 1.90-1.98(2 \mathrm{H}, \mathrm{m}), 2.01-2.05(2 \mathrm{H}, \mathrm{m})$, $3.25(1 \mathrm{H}, \mathrm{t}-\mathrm{like}, J=8.0 \mathrm{~Hz}), 4.91(1 \mathrm{H}, \mathrm{dd}, J=10.2,2.2 \mathrm{~Hz}), 5.00(1 \mathrm{H}$, dd, $J=16.8,2.2 \mathrm{~Hz}), 5.80(1 \mathrm{H}, \mathrm{m}) ;{ }^{13} \mathrm{C}-\mathrm{NMR}(75 \mathrm{MHz}) \delta 18.96(\mathrm{q}), 20.42(\mathrm{t})$, $25.82(\mathrm{t}), 28.93(\mathrm{t}), 29.13($ two t), $29.95(\mathrm{t}), 31.29(\mathrm{t}), 33.74(\mathrm{t}), 33.83(\mathrm{t})$, $34.66(\mathrm{t}), 36.62(\mathrm{~d}), 51.86(\mathrm{t}), 63.51$ (d), 71.31 (d), $114.00(\mathrm{t}), 138.98$ (d); MS m/z: $249\left(\mathrm{M}^{+}\right)$; HR-MS Calcd for $\mathrm{C}_{17} \mathrm{H}_{31} \mathrm{~N}$ 249.2455; Found 249.2450; $[\alpha]_{\mathrm{D}}^{26}-73.1^{\circ}\left(c=3.44, \mathrm{CHCl}_{3}\right)$.

Methyl 6-[5-(tert-Butyldiphenylsilyloxy)pent-1-enyl]-2-(3-methoxymethoxypropyl)-3-methylpiperidine-1-carboxylate (17) To a stirred solution of $(\mathrm{COCl})_{2}(0.14 \mathrm{ml}, 1.59 \mathrm{mmol})$ in $\mathrm{CH}_{2} \mathrm{Cl}_{2}(2 \mathrm{ml})$ was added DMSO $(0.22 \mathrm{ml}, 3.18 \mathrm{mmol})$ at $-78^{\circ} \mathrm{C}$, and the resulting solution was stirred at $-78^{\circ} \mathrm{C}$ for $5 \mathrm{~min}$. To the mixture was added dropwise a solution of $\mathbf{1 0}$ (300 mg, $1.04 \mathrm{mmol})$ in $\mathrm{CH}_{2} \mathrm{Cl}_{2}(2 \mathrm{ml})$ via a double-tipped stainless steel needle. After the reaction mixture was stirred for $30 \mathrm{~min}$ at $-78{ }^{\circ} \mathrm{C}$, triethylamine $(0.64 \mathrm{ml}, 4.77 \mathrm{mmol})$ was added to the reaction mixture. The reaction mixture was warmed to $0^{\circ} \mathrm{C}$ for $1 \mathrm{~h}$, and quenched with $\mathrm{H}_{2} \mathrm{O}$. The aqueous mixture was extracted with $\mathrm{Et}_{2} \mathrm{O}(10 \mathrm{ml} \times 3)$. The organic extracts were combined, dried, and evaporated to give pale yellow oil, which was used directly in the next step.

To a stirred suspension of TBDPSO $\left(\mathrm{CH}_{2}\right)_{4} \mathrm{P}^{+} \mathrm{Ph}_{3} \mathrm{Br}^{-}(2.72 \mathrm{~g}, 4.16 \mathrm{mmol})$ in THF $(18 \mathrm{ml})$ was added a solution of $n$-BuLi $(1.6 \mathrm{M}$ in hexane, $2.5 \mathrm{ml}$, $3.95 \mathrm{mmol}$ ) at $0{ }^{\circ} \mathrm{C}$, and the resulting orange solution was stirred at $0{ }^{\circ} \mathrm{C}$ for $10 \mathrm{~min}$. To the mixture was added dropwise a solution of the above aldehyde in THF ( $4 \mathrm{ml})$ via a double-tipped stainless needle. The reaction was stirred at room temperature for $21 \mathrm{~h}$, and quenched with $\mathrm{H}_{2} \mathrm{O}$. The aqueous mixture was extracted with $\mathrm{Et}_{2} \mathrm{O}(15 \mathrm{ml} \times 3)$. The organic extracts were combined, dried, and evaporated to give pale yellow oil, which was chromatographed on $\mathrm{SiO}_{2}(20 \mathrm{~g}$, hexane : acetone $=60: 1-20: 1)$ to afford $17(584 \mathrm{mg}, 97 \%)$ as pale yellow oil.

IR (neat) 2952, $1692 \mathrm{~cm}^{-1} ;{ }^{1} \mathrm{H}-\mathrm{NMR} \quad(500 \mathrm{MHz}) \quad \delta \quad 1.03 \quad(3 \mathrm{H}, \mathrm{d}$ $J=7.3 \mathrm{~Hz}), 1.07(9 \mathrm{H}, \mathrm{s}), 1.17-1.22(1 \mathrm{H}, \mathrm{m}), 1.27-1.33(1 \mathrm{H}, \mathrm{m}), 1.55-$ $1.93(9 \mathrm{H}$, br m) $2.17-2.23(1 \mathrm{H}, \mathrm{m}), 2.29-2.35(1 \mathrm{H}, \mathrm{m}), 3.37(3 \mathrm{H}, \mathrm{s})$, $3.49-3.57(2 \mathrm{~h}, \mathrm{~m}), 3.63(3 \mathrm{H}, \mathrm{s}), 3.69(2 \mathrm{H}, \mathrm{t}-\mathrm{like}, J=6.4 \mathrm{~Hz}), 3.92(1 \mathrm{H}, \mathrm{br})$, $4.62(2 \mathrm{H}, \mathrm{s}), 4.96(1 \mathrm{~h}, \mathrm{br}), 5.35-5.40(1 \mathrm{H}, \mathrm{m}), 5.56-5.60(1 \mathrm{H}, \mathrm{m}), 7.38-$ 7.45 (6H, m), $7.68-7.74(4 \mathrm{H}, \mathrm{m})$; MS m/z: $581\left(\mathrm{M}^{+}\right)$.

Methyl 6-(5-Hydroxypentyl)-2-(3-methoxymethoxypropyl)-3-methylpiperidine-1-carboxylate (18) To a stirred solution of 17 (581 mg, $1 \mathrm{mmol})$ in EtOAc $(20 \mathrm{ml})$ was added $10 \% \mathrm{Pd}-\mathrm{C}(100 \mathrm{mg})$, and the resulting suspension was hydrogenated under hydrogen atmosphere at $1 \mathrm{~atm}$ for $48 \mathrm{~h}$. The catalyst was removed by filtration and the filtrate was evaporated to give colorless oil, which was used directly in the next step.

To a stirred solution of the above oil in THF $(8 \mathrm{ml})$ was added a solution of TBAF ( $1 \mathrm{M}$ in THF, $1.1 \mathrm{ml}, 1.1 \mathrm{mmol})$ at $0{ }^{\circ} \mathrm{C}$, and the mixture was stirred at room temperature for $2 \mathrm{~h}$. The reaction was quenched with satd. $\mathrm{NH}_{4} \mathrm{Cl}$ (aq.), and the aqueous mixture was extracted with $\mathrm{CHCl}_{3}(10 \mathrm{ml} \times 7)$. The organic extracts were combined, dried, and evaporated to give colorless oil, which was chromatographed on $\mathrm{SiO}_{2}(20 \mathrm{~g}$, hexane : acetone $=15: 1-2: 1)$ to afford $18(246 \mathrm{mg}, 74 \%)$ as colorless oil.

IR (neat) $3444,2945,1678 \mathrm{~cm}^{-1} ;{ }^{1} \mathrm{H}-\mathrm{NMR}(500 \mathrm{MHz}) \delta 0.96(3 \mathrm{H}, \mathrm{d}$, $J=6.9 \mathrm{~Hz}), 1.12-1.83(16 \mathrm{H}$, br m) $, 2.43(1 \mathrm{H}, \mathrm{br}), 3.31(3 \mathrm{H}, \mathrm{s}), 3.47(2 \mathrm{H}$, $\mathrm{m}), 3.56(2 \mathrm{H}, \mathrm{t}$-like, $J=6.6 \mathrm{~Hz}), 3.62(3 \mathrm{H}, \mathrm{s}), 3.80(1 \mathrm{H}, \mathrm{br}), 4.06(1 \mathrm{H}, \mathrm{br})$, $4.56(2 \mathrm{H}, \mathrm{s}) ;{ }^{13} \mathrm{C}-\mathrm{NMR}(75 \mathrm{MHz}) \delta 19.35(\mathrm{q}), 21.70(\mathrm{t}), 22.22(\mathrm{t}), 25.47(\mathrm{t})$, $26.75(\mathrm{t}), 27.47(\mathrm{t}), 30.78(\mathrm{~d}), 32.54(\mathrm{t}), 32.96(\mathrm{t}), 35.26(\mathrm{t}), 50.64(\mathrm{~d}), 52.38$ (q), 55.03 (q), 56.65 (d), $62.46(\mathrm{t}), 67.52$ (t), 96.19 (t), 157.40 (s); MS m/z: $345\left(\mathrm{M}^{+}\right)$; HR-MS Calcd for $\mathrm{C}_{18} \mathrm{H}_{35} \mathrm{NO}_{5}$ 345.2513; Found 345.2533; $[\alpha]_{\mathrm{D}}^{26}$ $-9.0^{\circ}\left(c=4.71, \mathrm{CHCl}_{3}\right)$.

Methyl 6-Hex-5-enyl-2-(3-methoxymethoxypropyl)-3-methylpiperidine-1-carboxylate (19) To a stirred solution of $(\mathrm{COCl})_{2}(0.1 \mathrm{ml}$, $1.15 \mathrm{mmol})$ in $\mathrm{CH}_{2} \mathrm{Cl}_{2}(2 \mathrm{ml})$ was added DMSO $(0.17 \mathrm{ml}, 2.30 \mathrm{mmol})$ at $-78^{\circ} \mathrm{C}$, and the resulting solution was stirred at $-78^{\circ} \mathrm{C}$ for $5 \mathrm{~min}$. To the mixture was added dropwise a solution of $18(120 \mathrm{mg}, 0.35 \mathrm{mmol})$ in $\mathrm{CH}_{2} \mathrm{Cl}_{2}(2 \mathrm{ml})$ via a double-tipped stainless steel needle. After the reaction mixture was stirred for $30 \mathrm{~min}$ at $-78^{\circ} \mathrm{C}$, triethylamine $(0.5 \mathrm{ml}, 3.45 \mathrm{mmol})$ was added to the reaction mixture. The reaction mixture was warmed to $0^{\circ} \mathrm{C}$ for $1 \mathrm{~h}$, and quenched with $\mathrm{H}_{2} \mathrm{O}$. The aqueous mixture was extracted with $\mathrm{Et}_{2} \mathrm{O}(10 \mathrm{ml} \times 3)$. The organic extracts were combined, dried, and evaporated to give pale yellow oil, which was used directly in the next step.
To a stirred suspension of $\mathrm{MeP}^{+} \mathrm{Ph}_{3} \mathrm{I}^{-}(700 \mathrm{mg}, 1.74 \mathrm{mmol})$ in THF $(8 \mathrm{ml})$ was added a solution of $n$-BuLi $(1.6 \mathrm{M}$ in hexane, $1.04 \mathrm{ml}, 1.67 \mathrm{mmol})$ at $0^{\circ} \mathrm{C}$, and the resulting orange solution was stirred at $0{ }^{\circ} \mathrm{C}$ for $10 \mathrm{~min}$. To the mixture was added dropwise a solution of the above aldehyde in THF (4 ml) via a double-tipped stainless needle. The reaction was stirred at room temperature for $22 \mathrm{~h}$, and quenched with $\mathrm{H}_{2} \mathrm{O}$. The aqueous mixture was extracted with $\mathrm{Et}_{2} \mathrm{O}(15 \mathrm{ml} \times 3)$. The organic extracts were combined, dried, and evaporated to give pale yellow oil, which was chromatographed on $\mathrm{SiO}_{2}$ ( $20 \mathrm{~g}$, hexane $:$ acetone $=60: 1-20: 1)$ to afford $19(104 \mathrm{mg}, 88 \%)$ as pale yellow oil.

IR (neat) $3071,2942,1692 \mathrm{~cm}^{-1} ;{ }^{1} \mathrm{H}-\mathrm{NMR}(500 \mathrm{MHz}) \delta 1.00(3 \mathrm{H}, \mathrm{d}$, $J=6.8 \mathrm{~Hz}), 1.13-1.85(15 \mathrm{H}$, br m) $, 2.03(2 \mathrm{H}, \mathrm{q}-\mathrm{like}, J=7.3 \mathrm{~Hz}), 3.34(3 \mathrm{H}$, s), $3.48-3.54(2 \mathrm{H}, \mathrm{m}), 3.66(3 \mathrm{H}, \mathrm{s}), 3.80(1 \mathrm{H}, \mathrm{br}), 4.07(1 \mathrm{H}, \mathrm{br}), 4.60(2 \mathrm{H}$, s), $4.91(1 \mathrm{H}$, d-like, $J=10.3 \mathrm{~Hz}), 4.99(1 \mathrm{H}, \mathrm{d}-\mathrm{like}, J=15 \mathrm{~Hz}), 5.74-5.82$ $(1 \mathrm{H}, \mathrm{m}) ;{ }^{13} \mathrm{C}-\mathrm{NMR}(75 \mathrm{MHz}) \delta 19.42(\mathrm{q}), 21.78(\mathrm{t}), 22.17(\mathrm{t}), 26.71(\mathrm{t})$, $27.54(\mathrm{t}), 28.80(\mathrm{t}), 30.81(\mathrm{~d}), 33.04(\mathrm{t}), 33.70(\mathrm{t}), 35.19(\mathrm{t}), 50.87(\mathrm{~d}), 52.34$ (q), $55.06(\mathrm{q}), 56.66(\mathrm{t}), 96.24(\mathrm{t}), 114.18(\mathrm{t}), 138.71(\mathrm{~d}), 157.35(\mathrm{~s}) ; \mathrm{MS}$ $m / z$ : $341\left(\mathrm{M}^{+}\right)$; HR-MS Calcd for $\mathrm{C}_{19} \mathrm{H}_{35} \mathrm{NO}_{4}$ 341.2564, Found 341.2573; $[\alpha]_{\mathrm{D}}^{26}-5.2^{\circ}\left(c=3.93, \mathrm{CHCl}_{3}\right)$.

5-Hex-5-enyl-8-methyloctahydroindolizine (4) To a stirred solution of $n$-PrSH $(0.35 \mathrm{ml}, 3.81 \mathrm{mmol})$ in HMPA $(2.5 \mathrm{ml})$ was added a solution of $n$ $\operatorname{BuLi}(1.6 \mathrm{M}$ in hexane, $2.3 \mathrm{ml}, 3.63 \mathrm{mmol})$ at $0{ }^{\circ} \mathrm{C}$, and the reaction mixture was stirred at $0{ }^{\circ} \mathrm{C}$ for $30 \mathrm{~min}$. To the reaction mixture was added dropwise a solution of 19 ( $130 \mathrm{mg}, 0.38 \mathrm{mmol})$ in THF ( $3 \mathrm{ml})$ via a double-tipped stainless needle. The reaction was stirred at room temperature for $49 \mathrm{~h}$, and quenched with $28 \% \mathrm{NH}_{3}$ (aq.). The aqueous mixture was extracted with $\mathrm{Et}_{2} \mathrm{O}(10 \mathrm{ml} \times 10)$, and the organic extracts were combined, dried over $\mathrm{K}_{2} \mathrm{CO}_{3}$, and evaporated to give pale yellow oil, which was used directly in the next step.

To a solution of the above oil in $\mathrm{MeOH}(6 \mathrm{ml})$ was added conc. $\mathrm{HCl}(8$ drops), and the reaction mixture was heated at reflux for $1 \mathrm{~h}$. After cooling, the solvent was evaporated, and the residue was washed with $\mathrm{Et}_{2} \mathrm{O}$. To the residue was added $28 \% \mathrm{NH}_{3}$ (aq.), and the aqueous mixture was extracted with $\mathrm{CHCl}_{3}(10 \mathrm{ml} \times 10)$. The organic extracts were combined, dried over $\mathrm{K}_{2} \mathrm{CO}_{3}$, and evaporated to give pale yellow oil, which was used directly in the next step.

To a stirred solution of the above oil in $\mathrm{CH}_{2} \mathrm{Cl}_{2}(6 \mathrm{ml})$ were added $\mathrm{CBr}_{4}$ (177 mg, $0.53 \mathrm{mmol})$ and $\mathrm{Ph}_{3} \mathrm{P}(150 \mathrm{mg}, 0.57 \mathrm{mmol})$ at $0{ }^{\circ} \mathrm{C}$, and the resulting mixture was stirred at $0^{\circ} \mathrm{C}$ for $1 \mathrm{~h}$. To the reaction mixture was added triethylamine $(0.84 \mathrm{ml}, 6.10 \mathrm{mmol})$, and the stirring was continued for $30 \mathrm{~min}$ at room temperature. The volatiles were removed, and the residue was extracted with pentane $(5 \mathrm{ml} \times 4)$. The solvent was evaporated to give pale orange solid, which was chromatographed on $\mathrm{SiO}_{2}(20 \mathrm{~g}$, hexane : acetone $=20: 1)$ to afford $4(43 \mathrm{mg}, 51 \%)$ as pale yellow oil.

IR (neat) 3076, 2935, 2871, 2776, 2702, 1642, 1458, 1334, 1243, 1165, 1132, 1108, 1088, 992, $909 \mathrm{~cm}^{-1}$; ${ }^{1} \mathrm{H}-\mathrm{NMR}(500 \mathrm{MHz}) \delta 0.86(3 \mathrm{H}, \mathrm{d}$, $J=6.3 \mathrm{~Hz}), 0.93-0.98(1 \mathrm{H}, \mathrm{m}), 1.20-2.08(19 \mathrm{H}, \mathrm{br} \mathrm{m}), 3.30(1 \mathrm{H}, \mathrm{t}-\mathrm{like}$, $J=8.8 \mathrm{~Hz}), 4.91(1 \mathrm{H}, \mathrm{dm}, J=10.1 \mathrm{~Hz}), 4.99(1 \mathrm{H}, \mathrm{dm}, J=17.1 \mathrm{~Hz}), 5.73$ $5.86(1 \mathrm{H}, \mathrm{m}) ;{ }^{13} \mathrm{C}-\mathrm{NMR}(75 \mathrm{MHz}) \delta 18.95(\mathrm{q}), 20.36(\mathrm{t}), 25.39(\mathrm{t}), 28.98(\mathrm{t})$, $29.32(\mathrm{t}), 31.05(\mathrm{t}), 33.62(\mathrm{t}), 33.78(\mathrm{t}), 34.27(\mathrm{~d}), 51.78(\mathrm{t}), 63.67(\mathrm{~d}), 71.48$ (d), 114.25 (t), 138.84 (d); MS m/z: $221\left(\mathrm{M}^{+}\right)$; HR-MS Calcd for $\mathrm{C}_{15} \mathrm{H}_{27} \mathrm{~N}$ 221.2142 ; Found 221.2157; $[\alpha]_{\mathrm{D}}^{26}-103.9^{\circ}\left(c=0.60, \mathrm{CHCl}_{3}\right)$.

Acknowledgments We are grateful to Drs. Jhon W. Daly, Thomas F. Spande, and H. Martin Garraffo, NIH, for comparison of synthetic 237D with natural product. This work was supported in part by The Research Foundation for Pharmaceutical Sciences.

\section{References and Notes}

1) Daly J. W., J. Med. Chem., 46, 445-452 (2003).

2) Daly J. W., Garraffo H. M., Spande T. F., "Alkaloids: Chemical and Biological Perspective," Vol. 13, ed. by Pelletier S. W., Pergamon Press, New York, 1999, pp. 1-161.

3) Daly J. W., "The Alkaloids," Vol. 50, ed. by Cordell G. A., Academic Press, New York, 1998, pp. 141-169.

4) Tsuneki H., You Y., Toyooka N., Kagawa S., Kobayashi S., Sasaoka T., Nemoto H., Kimura I., Dani J. A., Mol. Pharmacol., 66, 1061-1069 (2004).

5) Chavez-Noriega L. E., Crona J. H., Washburn M. S., Urrutia A., Elliott K. L., Johnson E. C., J. Pharmacol. Exp. Ther, 280, 346-356 (1997).

6) Toyooka N., Nemoto H., "Studies in Natural Products Chemistry," Vol. 29, ed. by Atta-ur-Rahman, Elsevier, Amsterdam, 2003, pp. 419-448.

7) Toyooka N., Nemoto H., Recent Res. Devel. Organic Chem., 6, 611624 (2002). 
8) Toyooka N., Nemoto H., Trends in Heterocyclic Chemistry, 8, 145154 (2002)

9) Toyooka N., Kawasaki M., Nemoto H., Daly J. W., Spande T. F., Garraffo H. M., Heterocycles, 65, 5-8 (2005).

10) Toyooka N., Fukutome A., Shinoda H., Nemoto H., Angew. Chem. Int Ed., 42, 3808-3810 (2003).
11) Toyooka N., Fukutome A., Shinoda H., Nemoto H., Tetrahedron, 60, 6197-6216 (2004).

12) Corey E. J., Yuen P., Tetrahedron Lett., 30, 5825-5828 (1989).

13) Shishido Y., Kibayashi C., J. Org. Chem., 57, 2876-2883 (1992).

14) Comins D. L., LaMunyon D. H., Chen X., J. Org. Chem., 62, 81828187 (1997). 